\title{
Is Mode of Offshoring affected by Firm Capabilities and Service Characteristics? A Study of Large US Firms
}

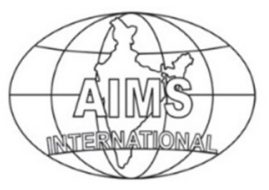

DOI: $10.26573 / 2018.12 .2 .3$

Volume 12, Number 2

May 2018, pp. 121-134

\author{
Anand Pore \\ University of Houston-Downtown \\ Houston, USA \\ (andypore@gmail.com)
}

As offshoring of services is increasingly becoming an important aspect of a company's strategy, this study explores the effects of firm capabilities such as firm size and service characteristics such as strategic importance of the service, customization needs of the service and proprietary nature of the service on the mode of offshoring of services. Also since the factors influencing the mode of service covered in this study are fairly generic and moreover this study plans to collect data from various industries, the results of this study will be of interest to practitioners from various industries and academicians focused on various aspects of offshoring of services.

Keywords: Offshoring, Mode of Offshoring, Firm Capabilities, Service Characteristics

\section{Introduction}

According to Ahearne and Kothandaraman (2009) because of increasing globalization companies are focusing more on their offshoring decisions and using it as strategic weapon in their armory. US Bureau of Economic Analysis (BEA) (2011) defines offshoring of services as the relocation of production of services from the US to a foreign location. Also various other terms are used to refer to this phenomena such as outsourcing, offshore outsourcing, sourcing, global sourcing and international sourcing (Pore, Shah \& Sterrett, 2012; Pore, 2013). Also the method by which a firm procures/produces services from/in a foreign location is referred to as Mode of offshoring. Additionally, various other terms such as 'mode of offshoring', 'offshoring mode', 'mode of sourcing', 'sourcing mode' and governance mode mean the same thing and are used interchangeably in the literature on offshoring (Pore et al, 2012; Pore, 2013).

Recently offshoring has received a lot of attention and as a result various top journals such as International Business Review (2011), Journal of International Business Studies (2009), Journal of International Management (2007) Journal of Management Studies (2005) and various other journals in the field of International Business (IB) and management field have had special issues devoted to this topic. Various aspects of offshoring ranging from the phenomena of offshoring (Jensen, Larsen \& Pedersen, 2013; Liesch, Buckley, Simon in \& Knight,2012; Schmeisser, 2013) to rationale for offshoring (Apte \& Mason, 1995; Mukherjee, Gaur \&Datta,2013) to location choice (Ghani, Kerr \& Stanton, 2014; Jensen \& Pedersen, 
2011;Liu, Feils \& Scholnick, 2011) to offshoring performance (Larsen, Manning \& Pedersen, 2013; Raman, Chadee, Roxas \& Michailova, 2013) to various other aspects of offshoring have been extensively researched but not much attention has been paid to 'how to source' (mode of offshoring) in the field of International Business (IB) and Management (Pore et al, 2012; Pore, 2013). Only a handful of studies (Lojacono, Misani \& Tallman, 2017; Pore et al, 2012; Pore, 2013) have looked at the mode of offshoring.

The reason mode of offshoring needs to be studied is that on one hand firms may be motivated to offshore services for variety of reasons such as cost reduction, accessing qualified personnel, provide $24 \times 7$ services to clients, speed up development of new products/services, access markets and so on and on the other hand firms may be hesitant to offshore services because of concerns over security/privacy of data, quality of service received from the overseas vendor, strategic importance of the service, host country risk, intellectual property rights protection and so on and if the firm choose wrong mode of offshoring then it may either not get the full benefits of offshoring or the entire offshoring project may fail. Hence mode of offshoring is an important factor that can affect the performance of the offshored service and that is why it needs to be studied further.

\subsection{Scope of this Study}

Various factors related to the service characteristics, firm capabilities, strategic motives, managerial concerns and many others may affect the mode of offshoring of services. This study explores the effects of firm capabilities such as firm size and service characteristics such as strategic importance of the service, customization needs of the service and proprietary nature of the service on the mode of offshoring of services. Also, this study focuses only on large firms as small and medium enterprises (SME) have limited resources, and because of this (lack of resources) SMEs are more likely to form joint ventures (Contractor \& Lorange, 1988; Fayerweather, 1982; Stopford \& Wells, 1972). According to Small Business Administration (SBA) US firms with more than five hundred employees are classified as large firms. Also, only offshoring of services and not goods is the focus of this study and only large US corporations irrespective of their industry are considered.

The next section discusses the effects of firm capabilities such as firm size and service characteristics such as strategic importance of the service, customization needs of the service and proprietary nature of the service on the mode of offshoring of services. Followed by research methodology and ways to test the propositions and the final section of the paper discusses the conclusion, implications and limitations of the study.

\section{Mode of Offshoring and Firm Capabilities and Characteristics 2.1 Mode of Offshoring}

According to Pore et al. (2012) and Pore (2013) the method by which a firm procures/produces services from/in a foreign location is referred to as mode of offshoring. Based on degree of control (Root, 1987) and level of resource commitment (Anderson \& Gatignon, 1986), firms can offshore services through a wide spectrum of modes ranging from i) complete internalization (foreign subsidiary) characterized by high degree of control and high level of resource 
commitment, to ii) complete externalization (arm's length transactions), characterized by low degree of control and low level of resource commitment or iii) intermediate cooperative modes (such as licensing, joint venture etc), characterized by medium degree of control and medium level of resource commitment.

\subsection{Capabilities}

According to Resource Based View (RBV), firm's resources and assets provide firm capabilities. Firm's size, international experience, managerial experience, other assets and resources provide firm capabilities that it can strategically deploy in a foreign market. When entering a foreign market, firm capabilities may enable or constrain the choice of offshoring mode.

Firm size is used in this study as a measure of firm capabilities. Other factors such as international experience and managerial experience are not used in this study, as Agarwal and Ramaswami (1992) found that firm size and multinational experience were highly correlated. Also, the researcher believes that managerial experience would also be highly correlated, with international experience and or firm size.

\subsubsection{Firm Size and Mode of Offshoring}

As large firms have the necessary resources, they tend to choose sole venture to coordinate activities on a global basis (Bartlett, 1986; Bartlett \& Ghoshal, 1986; Doz, Prahlad \& Hamel, 1988), whereas SMEs have limited resources and they (SMEs) are more likely to form joint ventures (Contractor \& Lorange, 1988; Fayerweather, 1982; Stopford \& Wells, 1972). According to Porter and Fuller (1986), large firms are more concerned with global strategic position than transaction costs associated with a given market.

Also, because of greater bargaining power to negotiate for greater ownership and control, large firms may be able to open sole ventures even in countries with restrictive investment policies (Lecraw, 1984). Another important reason for large firms to choose sole venture is that, even though large firms may be eligible to receive price reductions from suppliers (Mol, Van Tulder \& Beije, 2005), large firms may not find suppliers who would be able to supply them, because of the sheer volume of the services procured by them.

Because of all the above reasons increase in firm size would lead firm to internalize the offshoring operation rather than use a cooperative or external mode to produce/perform the service.

P1: As firm size increases, firms would prefer an internal mode of offshoring.

\subsection{Characteristics}

Characteristics refer to the characteristics of the service that is offshored. Service characteristics such as strategic importance of the service to the firm, need for customization of the service and proprietary nature of technology used to produce/perform the service may influence the mode of offshoring.

\subsubsection{Strategic Importance of the Offshored Service}

According to Porter (1980), the entry mode decision should not be narrowly focused on analysis of costs and investment requirements, but should consider the broader strategic issues. Corporate goals and objectives determine the entry mode, firms with 
aggressive goals and objectives favor entry modes that involve substantial resource commitment and control over the foreign operations and firms with limited goals and objectives favor entry modes involving minimal commitment of resources (Douglas \& Craig, 1995). Also, according to Oliver (1988), strategic choice plays a greater role in shaping the organizational structure than any other alternative factors.

Services that enable a firm to gain/maintain competitive advantage over the competition are considered strategically important to the firm. The higher the strategic importance of the product/service to the organization the less likely it will externalize that product/service (Bruck, 1995; Carmen \& Langeard 1980; Lovelock 1992; Prahlad \& Hamel 1990; Quinn \& Hilmer, 1995). According to RBV, using external sources for strategically important services may increase the chances of firm losing its competitiveness in case of opportunistic behavior by the supplier.

Murray and Kotabe (1999) divided services into core and supplementary services and argue that core services are usually performed by the firm itself. A similar argument is supported by Prahlad and Hamel (1990) and Lei and Slocum (1992). These researchers (Lei \& Slocum, 1992; Murray \& Kotabe, 1999; Prahlad \& Hamel, 1990) also suggest that supplementary services may be performed internally or externally.

"Core services are the necessary outputs of an organization that consumers are looking for, while supplementary services are either indispensable for the execution of the core service or are available only to improve the overall quality of the core service bundle." (Murray \& Kotabe, 1999:792)

According to Earl (1996), today's information technologies are so integrated that it may not be possible to clearly distinguish between core and non-core activities. This may result in organizations outsourcing the entire Information Technology (IT) functions, part of which may be core activity (Hancox \& Hackney, 1999). In these situations, the organization may seek higher level of control over vendor activities (Saunders, Gebelt \& Hu, 1997). Also, it is possible that core services may lose differential advantage and the firm may increase its reliance on supplementary services to enhance competitive advantage (Murray \& Kotabe, 1999). Hence, the researcher feels that, it is not necessarily the categorization of the service into core or supplementary service that drives the mode of offshoring, but the strategic importance of the service to the firm. Therefore, even a supplementary service could be sourced internally, if it is strategically important to the firm.

P2: The higher the strategic importance of the offshored service to the firm, the greater the firm's preference for an internal mode of offshoring.

\subsubsection{Customization}

Customizing service according to the customer's needs requires considerable knowledge about the service. Moreover, increase in customization requires an increase in the service provider's investment in physical and human resources and may also involve specialized assets (Erramilli \& Rao, 1993). Furthermore, these investments in physical and human resources may not be useful outside the specific transaction under consideration (Anderson \& Gatignon, 1986; Erramilli \& Rao, 1993; Williamson, 1981b). According to Transaction Cost Analysis (TCA), increase in customization results in increase in asset specificity. 
A basic tenet of TCA is that, increase in asset specificity, increases the hazards associated with market-based exchange and increases the need for internalizing the transaction (Williamson, 1975; 1985). Several studies (Anderson \& Gatignon, 1986; Anderson \& Coughlan, 1987; Davidson \& McFetridge, 1985; Erramilli \& Rao, 1993; Gatignon \& Anderson, 1988; Kim \& Hwang, 1992) found that degree of control (level of ownership) was positively related to the degree of asset specificity, whereas a study by Osborn and Baughn (1990) did not support this (positive relationship between asset specificity and level of control).

Coase (1937) argued that increase in asset specificity alone may not be enough to ignore market based transaction. Also, according to RBV, core activity must be performed internally and supplementary services may be performed internally or externally (Prahlad \& Hamel, 1990). Hence even with the increase in the customization needs (asset specificity) for the service, the firm may not want to use internal mode of offshoring, if the service is not strategically important to the firm.

P3a: Increase in customization needs (asset specificity) for the service will not lead to firm using internal mode of offshoring.

P3b: As the need for customization of the service increases, the firm would prefer to use an internal mode over either a cooperative or an external mode (and prefer a cooperative mode over an external mode) of offshoring, but only when the strategic importance of the offshored service is high.

\subsubsection{Proprietary Technology}

According to Murray, Kotabe and Wildt (1995), proprietary technology is the unique technology, such as technological know-how and marketing and management skills possessed by a firm. Proprietary nature of a firm's assets is a major product-related factor influencing market entry strategies (Ekeledo \& Sivakumar, 1998). Ekeledo and Sivakumar (2004) argue that a firm can protect its proprietary know-how by maintaining full control over production functions. Moreover, according to Ekeledo and Sivakumar (1998), a service firm is more likely to adopt the sole ownership mode when it wants to protect its proprietary assets, as intellectual property laws vary throughout the world and the enforcement of such laws even in the countries that have intellectual property laws is questionable.

Several researchers (Caves, 1982; Davidson, 1982; Davidson \& McFetridge, 1984; Stopford \& Wells, 1972; Telesio, 1979) have found a positive relationship between research and development expenditures (which generate proprietary knowledge) and direct investment by firms in foreign operations.

Both TCA and RBV support the use of sole ownership for proprietary technology, but a firm needs to balance the need for integration with the costs of controlling the hierarchical structure, when protecting its proprietary know-how by integrating its foreign operations (Erramilli \& Rao, 1993; Hennart, 1989).According to TCA, firms tend to select entry modes that balance the advantages of integration with the additional costs of control (Brouthers, 2002). Williamson (1979; 1983) argue that, a firm can benefit from the scale economies of the marketplace by sourcing components that involve no proprietary technology, and thus avoiding the bureaucratic disadvantages that accompany internal sourcing. This argument could 
be extended to services that are produced/performed with the use of proprietary technology that is not strategically important to the firm.

As technology rapidly changes, firms are unwilling to invest in new and even for that matter old proprietary technologies (that are not strategically important to the firm) and hence would prefer to purchase these services, even if proprietary technologies are used in their production. According to Kotabe, Murray and Javalgi (1998), internal sourcing of supplementary services tends to dilute a firm's core service competencies.

A firm may select sole ownership as an entry mode, in order to protect the proprietary content of a product (Anderson \& Gatignon 1986). This argument could be extended to services and hence depending upon the need to protect the proprietary content of the services or in other words if the service using proprietary technology is of strategic importance to the firm, then the firm would be more likely to use internal mode of offshoring.

P4a: Increase in proprietary nature of technology used in production/performance of the service, will not result in increase in firm using internal mode of offshoring.

P4b:As the proprietary nature of technology used in production/performance of the service increases, the firm would prefer to use an internal mode over either a cooperative or an external mode (and prefer a cooperative mode over an external mode) of offshoring, but only when the strategic importance of the offshored service is high.

\subsection{Sample}

\section{Research Methodology}

Information needed to test the propositions in this paper could be obtained by sending a link to an online survey to senior executives in a firm. Mailing hard copies of surveys is very time consuming and expensive and online surveys offer a very efficient and cost effective option for gathering survey data. Also, senior executives in a firm are more likely to have information or be involved in the decision making process regarding important decisions such as entry mode choice of the firm and would be an excellent source for such information (Agarwal \& Ramaswami, 1992; Erramilli \& Rao, 1990; 1993; Kotabe et al., 1998; Murray \& Kotabe, 1999; Pore et al, 2012; Pore, 2013). Various company websites and Dun \& Bradstreet's Million Dollar Database, Hoover's (a Dun \& Bradstreet company) will be used to collect email addresses of top executives of various firms.

\subsection{Unit of Analysis}

Some previous studies (Kotabe et al., 1998; Murray \& Kotabe, 1999) have used the entire firm as the unit of analysis but according to (Pore et al, 2012; Pore, 2013) increasingly more and more companies are involved in offshoring various services from multiple locations from all over the globe and hence using the entire firm or a subsidiary of the firm as a unit of analysis does not make sense. Also according to Pore et al. (2012) and Pore (2013) if the entire firm or the subsidiary is used as the unit of analysis then the person responding to the survey may not have complete knowledge of the various offshoring activities of the firm. In addition different functions along the value chain may be sourced for different reasons and hence 
aggregate information about the offshoring activities of the firm or the subsidiary may not make sense and hence the unit of analysis for this study will be one offshored service function.

\subsection{Operationalization of Variables}

Various studies (e.g., Jordan \& Turner, 2008; Kwon \& Ko, 2006; Kwon \& Trail, 2005; Nagy, 2002; Wanous \& Hudy, 2001; Wanous \& Reichers, 1996; Wanous, Reicher \& Hudy, 1997) have used single-item measures for collecting self-reported data and hence this study will also use single-item measures.

\subsubsection{Dependent Variable}

\subsubsection{Mode of Offshoring}

Previous studies (Esther Sanchez-Peinado et al., 2007; Brouthers \& Brouthers 2003; Brouthers, 2002; Murray \& Kotabe, 1999; Kwon \& Konopa, 1993; Erramilli \& Rao, 1993) conceptualized mode of entry as a dichotomous variable. Also a practical reason for using this variable as a dichotomous variable, is that the likelihood of the determinants registering significant increases with decrease in the number of possible values for the dependent variable. Pan. Li and Tse (1999) reached a similar conclusion as far as the number of determinants registering significant is concerned. Erramilli and Rao (1990) came up with nine sourcing modes and arranged them in an ordinal scale based on involvement (1=lowest, 9=highest). In a later study Erramilli and Rao (1993) collapsed the entry modes into two categories, shared controlled mode and full control mode.

Meyer (2001) used four values for mode of entry (trade, contractual arrangement, joint ventures and wholly owned subsidiary). Ekledo and Sivkumar (1998) also used four values for entry modes (franchising/licensing, exporting, joint ventures and wholly owned operations). Whereas, Lacity and Willcocks (1998) came up with three sourcing modes; total insourcing, total outsourcing and mixed sourcing. Along similar lines Pore et al. (2012) and Pore (2013) operationalized mode of offshoring as an ordinal variable with three possible values: Mode of Offshoring $=1$ for External sourcing or externalization, $=2$ for Cooperative sourcing and $=3$ for Internal sourcing or internalization. This study will do the same and follow Pore et al. (2012) and Pore (2013) method of operationalizing mode of offshoring

\subsubsection{Independent Variables}

A 5-point Likert scale will be used to collect data on independent variables.

\subsubsection{Firm Size}

Various measures have been used by researchers for firm size such as sales volume (Esther Sanchez-Peinado et al., 2007; Agarwal \& Ramaswami, 1992), total assets (Kogut and Singh 1988), three-item scale (global sales, U.S. and worldwide employment) (Aulakh \& Kotabe, 1997) and number of employees (Brouthers, 2002; Erramilli \& Rao, 1993; Gatignon \& Anderson, 1988). Because of inter-country differences in accounting standards, number of employees makes more sense as a measure of firm size than other measures of firm size as the other measures may not be consistent across different countries (Brouthers \& Nakos, 2004).

Hence total number of employees worldwide is used as a measure of firm size. 


\subsubsection{Strategic Importance of the Offshored Service}

Murray and Kotabe, (1999) divided services into core and supplementary services. The researcher believes that strategic importance of the offshored service to the firm is a straight forward variable trying to understand how important the service is to the firm and hence could be measured using a single-item measure.

\subsubsection{Customization}

Variables related to the asset-specificity of the service have been used by Erramili and Rao (1993). Erramili and Rao used customization as an item of asset specificity scale which was comprised of 3 items; professional skills, specialized know-how and customization, all measured on a 5-point Likert scale. Murray et. al. (1995) measured asset specificity as a single-item measure using a 6-point Likert scale.

This variable measures the level of customization required (by the consumer) in producing/performing the offshored service and the researcher believes is a straight forward measure, also this variable has been measured by Murray et. al. (1995) using a single-item measure. Hence it would be appropriate to measure this variable using single-item measure.

\subsubsection{Proprietary Technology}

Researchers (Agarwal \& Ramaswami, 1992; Murray \& Kotabe, 1990; Murray et al., 1995; Porter, 1980, 1985) have used operational measures related to either product technology, process technology and/or managerial technology as measures of proprietary technology.

Proprietary technology in IB and strategic management field has been measured by various scholars (Wernerfelt, 1989; Grosse, 1996; Gomes-Casseres, 1989; Agarwal \& Ramaswami, 1992; Storey \& Easingwood, 1996; Williams, 1992; Grant, 1991; Goodnow, 1985; Porter, 1980, 1985) using 21 different items: unique patents/number of patents: trademark; trade secret; logistic and distribution technology; frequency of new product development; quality of the product; product innovation; brand name: research and development technology; product technology; process technology; managerial technology; unique benefits; product difficulty for competition to copy; improvement over existing products: low cost production and product differentiation and focus. This list was derived from Ekledo (2000) and is by no means exhaustive. As we can see twenty one items have been used by various researchers to measure proprietary technology, with no consensus between researchers as to which is a better measure of proprietary technology. The researcher believes that a single-item measure based on managerial perception to measure proprietary technology would be appropriate for this study.

\subsection{Pilot Survey}

Online Pilot survey will be created and modified based on the advice of five managers involved in the decision making process of offshoring of services and five professors involved in offshoring research. . The content validity for the survey will be provided by the professors and the face validity will be provided by the managers.

\section{Conclusion, Limitations and Implications}

This study plans to test the effects of firm capabilities such as firm size and service characteristics such as strategic importance of the service, customization needs of the 
service and proprietary nature of the service on the mode of offshoring of services.

The limitations of this study and similar studies are that they are only narrowly focused only on certain aspects of offshoring. Firm size is used in this study as a measure of firm capabilities. Other factors such as international experience and managerial experience are not used in this study and could be used in addition or in lieu of firm size as a measure of firm capability. Agarwal and Ramaswami (1992) found that firm size and multinational experience were highly correlated. Also, the researcher believes that managerial experience would also be highly correlated, with international experience and/or firm size.

Another limitation of this study is that this study only uses strategic importance of the service to the firm, need for customization of the service and proprietary nature of technology used to produce/perform the service as measures of service characteristics but there are numerous other factors such availability of skilled personnel, concerns over security/privacy of data, quality of service received from the overseas vendor, host country risk, intellectual property rights protection and so on that could play an important role in deciding the mode of offshoring.

Even though on the surface these limitations may look like valid limitations but in practice it is not possible for one study to look at all the various factors influencing all the different modes of offshoring of services. Also this study only focuses on large firms as small and medium sized firms lack the necessary resources to engage in various modes of offshoring (Contractor \& Lorange, 1988; Fayerweather, 1982; Stopford \& Wells, 1972).

Also since the factors influencing the mode of service covered in this study are fairly generic and moreover this study plans to collect data from various industries, the results of this study will be of interest to practitioners from various industries and academicians focused on various aspects of offshoring of services.

\section{References}

1. Ahearne, M., \& Kothandaraman, P., 'Impact of outsourcing on business tobusiness marketing: An agenda for inquiry', Industrial Marketing Management, 38(4), 2009, 376-378.

2. Agarwal, S. \& S.N. Ramaswami., 'Choice of Foreign Market Entry Mode: Impact of Ownership, Location and Internalization Factors', Journal of International Business Studies, 23, 1992, 1-27.

3. Anderson, E. \& Coughlan, A. T., 'International Market Entry and Expansion via Independent or Integrated Channels of Distribution', Journal of Marketing, 51 (January), 1987 71-82.

4. Anderson, E. \& Gatignon, H., 'Modes of Entry: A Transaction Cost Analysis and Propositions', Journal of International Business Studies17 (fall), 1986, 1-26.

5. Apte, U. M., \& Mason, R. O., 'Global disaggregation of information-intensive services', Management Science, 41(7), 1995, 1250-1262.

6. Aulakh, P.S. \& Kotabe, M., 'Antecedents and Performance Implications of Channel Integration in Foreign Markets', Journal of International Business Studies 28, 1997, 145-175.

7. Brouthers, K.D., 'Institutional, Cultural and Transaction Cost Influences on Entry Mode Choice and Performance', Journal of International Business Studies, 33(2), 2002, 203-222. 
8. Brouthers, K. D. \& Brouthers, L. E., 'Why Service and Manufacturing Entry Mode Choices Differ: The Influence of Transaction Cost Factors, Risk and Trust', Journal of Management Studies 40(5), 2003, 1179-1204.

9. Bureau of Economic Analysis, 'Summary data for trade in private services by type', retrieved electronically on 2/08/2011 from http://www.bea.gov/international/index.htm\#trade

10. Carman, J.M. \& Langeard, E., 'Growth Strategies for Service Firms', Strategic Management Journal, 1 (1), 1980, 7-22.

11. Caves, R. E., Multinational Enterprise and Economic Analysis, New York: Cambridge University Press, 1982.

12. Coase, R. H., 'The Nature of the Firm', Economical, 4, 1937, 386-405.

13. Contractor, F. J. \& Lorange, P., 'Why Should Firms Cooperate? The Strategy and Economics Basis for Cooperative Ventures', Cooperative Strategies in International Business (Lexington, MA: Lexington Books), 1988.

14. Davidson, W. H. (1982), Global Strategic Management. New York: John Wiley \& Sons, 1982.

15. Davidson, W. H. \& McFetridge, D. G., 'Key Characteristics in the Choice of International Transfer Mode', Journal of International Business Studies, I6 (summer), $1985,5-22$.

16. Douglas, S. P. \& Craig, C. S., Global Marketing Strategy. New York: McGrawHill, Inc, 1995.

17. Earl, J. M., 'The Risks of Outsourcing IT', Sloan Management Review, 37 (3), 1996, 26-32.

18. Ekeledo, I., 'Choice of foreign market entry mode: A resource-based approach', (Doctoral dissertation, University of Illinois, Chicago), 2000.

19. Ekeledo, I. \& Sivakumar, K., 'Foreign Market Entry Mode Choice of Service Firms: A Contingency Perspective', Journal of the Academy of Marketing Science, 26(4), 1998, $274-292$.

20. Ekeledo, I. \& Sivakumar, K., 'International Market Entry Mode Strategies of Manufacturing Firms and Service Firms: A Resource-Based Perspective', International Marketing Review, 21 (1), 2004, 68-101.

21. Erramilli, M. K. \& Rao, C. P., 'Choice of Foreign Market Entry Modes by Service Firms: Role of Market Knowledge', Management International Review, 30(2), 1990, 135-150.

22. Erramilli, M. K. \& Rao, C. P., 'Service firms' international entry mode choice: a modified transaction-cost analysis approach', Journal of Marketing, 57 (3), 1993, 19-38.

23. Fayerweather, J., International business strategy and administration. Cambridge: Ballinger, 1982.

24. Gatignon, H. \& Anderson, E., 'The Multinational Corporation's Degree of Control Over Foreign Subsidiaries: An Empirical Test of A Transaction Cost Explanation', Journal of Law, Economics and Organization, 4(FaIl), 1988, 305-336.

25. Ghani, E., Kerr, W. R., \& Stanton, C., 'Diasporas and outsourcing: evidence from o Desk and India', Management Science, 60(7), 2014, 1677-1697.

26. Gomes - Casseres, B., 'Ownership Structures of Foreign Subsidiaries: Theory and Evidence', Journal of Economic Behavior and Organization, 11, 1989, 1-25. 
27. Grant, Robert M., 'The Resource-Based Theory of Competitive Advantage: Implications for Strategy Formulation', California Management Review, spring, $1991,114-135$.

28. Grosse, Robert, 'International Technology Transfer in Services', Journal of International Business Studies, Fourth Quarter, 1996, 781 - 800.

29. Good now, J. D., 'Developments in International Mode of Entry Analysis', International Marketing Review, 2 (autumn), 1985, 17-30.

30. Hancox, M. \& Hackney, R., 'Information Technology Outsourcing: Conceptualizing Practice in the Public and Private Sector', Proceedings of the 32nd Annual Hawaii International Conference on System Sciences, 1999.

31. Hennart, J., 'Can the 'New Forms of Investment' Substitute for the 'Old Forms?' A Transaction Costs Perspective', Journal of International Business Studies, 20 (summer), 1989, 211 -234.

32. Jensen, P. D. O., \& Pedersen, T., 'The economic geography of offshoring: the fit between activities and local context', Journal of Management Studies, 48(2), 2011, 352-372.

33. Jensen, P. D. O., Larsen, M. M., \& Pedersen, T., 'The organizational design of offshoring: taking stock and moving forward', Journal of International Management, 19(4), 2013, 315-323.

34. Jordan, J. S. \& Turner, B. A., 'The feasibility of single-item measures for organizational justice', Measurement in Physical Education and Exercise Science, 12, 2008, 237-257.

35. Kim, W.C. \& Hwang, P., 'Global Strategy and Multinationals' Entry Mode Choice', Journal of International Business Studies, 23, 1992, 29-53.

36. Kogut, B. \& Singh, H., 'The Effect of National Culture on the Choice of Entry Mode', Journal of International Business Studies, 19, 1988, 411-432.

37. Kotabe, M., Murray, J..Y. \& Javalgi, R. G., 'Global sourcing of services and market performance: an empirical investigation', Journal of International Marketing 6 (4), 1998, 10- 31.

38. Kwon, H., \& Ko, Y., 'Validation of single-item measure of Scale of Service Quality for Recreational Sports (SSQRS)', International Journal of Sport Management, 7(1), 2006, 110-120.

39. Kwon, H., \& Trail, G., 'The feasibility of single-item measures in sport loyalty research', Sport Management Review, 8, 2005, 68-89.

40. Kwon, Y \& Konopa, L. J., 'Impact of Host Country Market Characteristics on the Choice of Foreign Market Entry Mode', International Marketing Review, 10(2), 1993, 60-76.

41. Lacity, M. C, Willcocks, L. P., 'An Empirical Investigation of Information Technology Sourcing Practices: Lessons from Experience', MIS Quarterly, 22 (3), 1998, 363-408

42. Larsen, M. M., Manning, S., \& Pedersen, T., 'Uncovering the hidden costs of offshoring: the interplay of complexity, organizational design, and experience', Strategic Management Journal, 34(5), 2013, 533-552.

43. Lecraw, D. J., 'Bargaining power, ownership, and profitability of subsidiaries of transnational corporations in developing countries', Journal of International Business, 15, Spring/Summer 1984, 27-44.

44. Lei, D. \& Slocum, J. W. Jr., 'Global strategy, competence-building and strategic alliances', California Management Review, Fall 1992, 81-97. 
45. Liesch, P. W., Buckley, P. J., Simon in, B. L., \& Knight, G., 'Organizing the modern firm in the worldwide market for market transactions', Management International Review, 52(1), 2012, 3-21.

46. Liu, R., Feils, D. J., \& Scholnick, B., 'Why are different services outsourced to different countries?', Journal of International Business Studies, 42(4), 2011, $558-571$.

47. Lojacono, G., Nicola Misani, N. \& Tallman, S., 'Offshoring, local market entry, and the strategic context of cross-border alliances: The impact on the governance mode', International Business Review, 26(3), 2017, 435-447.

48. Lovelock, C. H., 'A basic toolkit for service managers', In C. H. Lovelock (ed.), Managing Services: Marketing, Operations, and Human Resources. PrenticeHall, Englewood Cliffs, NJ, 1992, 17-30.

49. Manning, S., 'Mitigate, tolerate or relocate? Offshoring challenges, strategic imperatives and resource constraints', Journal of World Business, 49(4), 2014, 522-535.

50. Meyer, K.E., Institutions, Transaction Costs, and Entry Mode Choice in Eastern Europe', Journal of International Business Studies 32, 2001, 357-367.

51. Mol, M. J., Van Tulder, R. J. M. \& Beije, P.R., 'Antecedents and performance consequences of international outsourcing', International Business Review, 14, 2005, 599-617

52. Mukherjee, D., Gaur, A. S., \& Datta, A., 'Creating value through offshore outsourcing: an integrative framework', Journal of International Management, 19(4), 2013, 377-389.

53. Murray, J.Y., \& Kotabe, M., 'Sourcing Strategies of U.S. Service Companies: A Modified Transaction-Cost Analysis', Strategic Management Journal, 20, 1999, 791-809.

54. Murray, J.Y., Kotabe, M. \& Wildt, A. R., 'Strategic and Financial Performance Implications of Global Sourcing Strategy: A Contingency Analysis', Journal of International Business Studies, 26, 1995, 181-202.

55. Nagy, M. S., 'Using a single-item approach to measure facet job satisfaction', Journal of Occupational and Organizational Psychology, 75, 2002, 77-86.

56. Oliver, C., 'The Collective Strategy Framework: An Application to Competing Predictions of Isomorphism', Administrative Sciences Quarterly, 33, December 1988, 543-561.

57. Osborn, R. N. \& Baughn, C. C., 'Forms of inter organizational governance for multinational alliances', Academy of Management Journal, 33, 1990, 503-519.

58. Pan, Y., Li, S. \& Tse. D. K., 'The Impact of Order and Mode of Market Entry on Profitability and Market Share', Journal of International Business Studies, 30, 1990, 81-103.

59. Pore, A., 'The Effects of Managerial Concerns on Mode of Offshoring: A Study of Large US Corporations', The Journal of International Business Research and Practice, Vol. 7, 2013, pp. $34-45$.

60. Pore, A., Shah, G. \& Sterrett, J., 'Do Managerial Motives Influence the Mode of Offshoring...?', Journal of Interdisciplinary Business Studies, Vol 1, 2012, pp 1 $-22$.

61. Porter, M. E., Competitive Strategy: Techniques for Analyzing Industries and Competitors, New York: Free Press, 1980. 
62. Porter, M. E., Competitive Advantage: Creating and Sustaining Superior Performance, New York, London: Free Press; Collier Macmillan, 1985.

63. Prahalad, C. K.. \& Hamel, G., 'The Core Competence of the Corporation', Harvard Business Review, (May-June), 1990, 79-91.

64. Quinn, J.B. \& Hilmer, F. G., 'Strategic out sourcing', The McKinsey Quarterly1, 1995, 49-70.

65. Raman, R., Chadee, D., Roxas, B., \& Michailova, S., 'Effects of partnership quality, talent management, and global mindset on performance of offshore IT service providers in India', Journal of International Management, 19(4), 2013, 333-346.

66. Root, F.R., Entry strategies for international markets. Lexington: D.C. Heath, 1987.

67. Saunders, C., Gebelt, M. \& Hu, Q., 'Achieving success in information systems outsourcing, California Management Review, 39 (2), 1997, 63:79

68. Schmeisser, B., 'A systematic review of literature on offshoring of value chain activities', Journal of International Management, 19(4), 2013, 390-406.

69. Stopford, J. M. \& Wells, L.T., Managing the Multinational Enterprise: Organization of the Firm and Ownership of the Subsidiaries. New York: Basic Books, 1972.

70. Storey, C. D. \& Easing wood, C. J., 'Determinants of New Product Performance: A Study in the Financial Services Sector', International Journal of Service Industry Management, 7(1), 1996, 32 - 55.

71. Telesio, P., Technology Licensing and Multinational Enterprise. Praeger, New York, 1979.

72. Wanous, J. P., \& Hudy, M. J., 'Single-item reliability: A replication and extension', Organizational Research Methods, 4(4), 2001, 361-375.

73. Wanous, J. P., \& Reichers, A. E., 'Estimating the reliability of a single-item measure', Psychological Reports, 78, 1996, 631-634.

74. Wanous, J. P., Reichers, A. E., \& Hudy, M. J., 'Overall job satisfaction: How good are the single-item measures?', Journal of Applied Psychology, 82, 1997, 247-252.

75. Wernerfelt, B., 'From Critical Resources to Corporate Strategy', Journal of General Management, 14, 3, spring 1989, 4 - 12.

76. Williams, J. R., 'How Sustainable is Your Competitive Advantage', California Management Review, spring 1992, 29-51.

77. Williamson, O. E., Markets and Hierarchies, Analysis and Antitrust Implications: A Study in the Economics of Internal Organization, New York: Free Press, 1975.

78. Williamson, O. E., 'Transaction Cost Economics: The Governance of Contractual Relations', Journal of Law and Economics, 22, October 1979, 233 262.

79. Williamson, O. E., 'The Modern Corporation: Origins, Evolution, Attributes', Journal of Economics Literature, 19, December 1981b, 1537- 1568.

80. Williamson, O. E., 'Organizational innovation: The transaction-cost approach', In Joshua Ronen, editor, Entrepreneur ship, Lexington, Mass.: Lexington Books, 1983, 101-103.

81. Williamson, O. E., 'The Economic Institutions of Capitalism: Firms, Markets, Relational Contracting', New York, London: Free Press, Collier Macmillan, 1985. 
About Our Author

Anand Pore has earned his $\mathrm{PhD}$ from Rutgers University, NJ. Currently he is working as an Assistant Professor at University of Houston-Downtown, Houston, TX. He teaches graduate and undergraduate courses primarily in the areas of strategy, international business and leadership. His research interests include: international business strategies, effectiveness of various teaching methods and humanistic capitalism. Also, he has more than nineteen years of professional experience working in various capacities ranging from Network Engineer to Vice President in the Information Technology field and has worked for various companies such as Chase, Johnson \& Johnson, The Prudential, AT\&T, Mars and Mars, Delta Consultancy Services and Tata Unisys. 